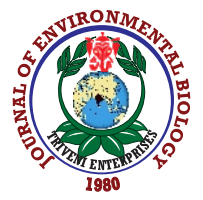

\title{
Integrated management of seasonal fishing closures and fisheries stock rebuilding plans for recovering marine stocks in Korea
}

\author{
Sang-Go Lee ${ }^{1}$, Md. Hashmi Sakib ${ }^{1,2 *}$ and M. Aminur Rahman ${ }^{1,3}$ \\ 'World Fisheries University Pilot Programme, Pukyong National University, 365 Sinseon-ro, Nam-gu, Busan 48547, Republic of Korea \\ ${ }^{2}$ Department of Agricultural Extension and Rural Development, EXIM Bank Agricultural University Bangladesh, Chapainawabganj 6300, Bangladesh \\ ${ }^{3}$ Department of Fisheries and Marine Bioscience, Faculty of Biological Science and Technology, Jashore University of Science and Technology, \\ Jashore 7408, Bangladesh
}

*Corresponding Author Email : sakib20067@gmail.com

\section{Abstract}

Aim: Fisheries stock rebuilding plans (FSRP) and seasonal area closures have not yet reached the desired stock level as they were implemented separately. Therefore, these two policies were integrated in this study to determine the nature of stock enhancement.

Methodology: FSRP and seasonal closures were integrated in this study to determine the nature of stock enhancement of targeted marine species (sandfish, blue crab, octopus, skate ray, and yellow croaker). In contrast, tokobushi abalone, cod, filefish, Korean flounder, and purplish Washington clam were managed only by FSRP. The catch per unit effort (CPUE) was examined to evaluate the improvement of depleted stocks.

Results: Overall, stocks showed expected recovery during FSRP with seasonal closure. CPUEs of blue crab, octopus, skate ray, and yellow croaker significantly increased during the period of integrated policy implementation. Stock reclamation was found higher within the first five years than ten years of FSRP regime. Blue crab, yellow croaker and skate ray showed similar fluctuations in the abundance. Only the abundance of cod increased significantly by FSRP with the year-round open fishery.

Interpretation: Integrated management seemed a suitable means for marine stock management. Planning for every five-year investigation to ensure sound ecological interaction of all components will contribute more to combined management practices.

Key words: Combined, Ecosystem, Marine policy, Seasonal closure, Stock rebuilding

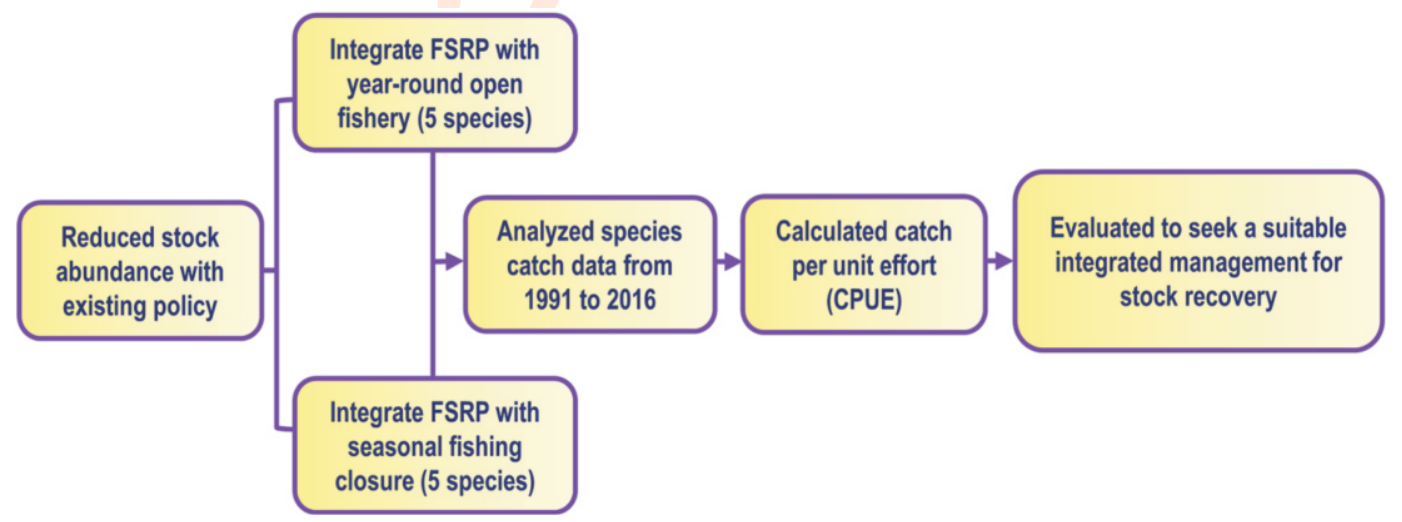

How to cite : Lee, Sang-Go, Md. Hashmi Sakib and M. Aminur Rahman: Integrated management of seasonal fishing closures and fisheries stock rebuilding plans for recovering marine stocks in Korea. J. Environ. Biol., 41, 1326-1338 (2020). 


\section{Introduction}

Globally, the fisheries sector provide animal protein, employment, goods and services for the wellbeing of mankind. This sector often suffers with declined marine stocks due to overexploitation of aquatic organisms to meet seafood demand (Rice and Garcia, 2011; Ye et al., 2013; Olesen et al., 2015). In some places, the recent policies have been opted to harvest below the maximum sustainable yield for reducing overexploitation of marine resources (Melnychuk et al., 2013). Also, some useful fisheries management strategies have been implemented to avoid overexploitation and prevent reduction in fisheries resources (Walker et al., 2018). Thus, successful input control methods such as closed seasons, vessel buyback, and fishing licenses should be established to keep healthy fish stocks by optimizing fishing efforts (Pope, 2009).

Input control is the prime priority to solve these issues regarding overexploitation. In Korea, some input control measures have been applied to continue fishing in a sustainable manner with increased fishing pressure (Zhang et al., 2014). Therefore, gear restriction, vessel licensing and vessel buyback policies have been also implemented by the Korean government agencies to lower the fishing capacity for reducing annual fishing mortality (Lee and Midani, 2015). As an input control method, the seasonal fishing closure limits the fishing days in spawning seasons to increase the recruitment of juveniles for improving stock status (Simões et al., 2017). It also allows a large amount of spawning to produce eggs. Over the last couple of decades, seasonal closure has been applied to avoid additional fishing pressure, habitat disturbance and drastic disappearance of species (Demestre et al., 2008).

On the other hand, taxes and individual transferable quotas (ITQ) can be added as output control measures to eliminate inefficient vessel systematically (Clarke et al., 2015). Although the profitability of fishery can be increased with ITQ management system, the government can not decide to use it due to having a possibility for facing a significant reduction in employment (Merayo et al., 2018). To handle these issues, closed fishing season has been adopted as a technical measure with a hope to improve biomass of some selected commercial species. All input control measures emphasize on finding out a way to improve marine resources in Korea. Eventually, not only the landing trends of some species have been quite unstable until 2000 , but also couple of them have collapsed within a short period of time (Lee and Midani, 2014a, 2014b).

Seasonal fishing closure has been incorporated with fisheries stock rebuilding plans (FSRP). To enhance critically endangered species with some strategic means to make it more effective to enrich the stocks (Lee and Midani, 2014a). According to FSRP principles, some habitat reconstruction programs have been implemented, such as seagrass plantation, juvenile fish release, and installation of artificial coral reef for making a suitable home for marine creatures. In the multi-species fishery, every single species has their own unique characters, which invite some ecological challenges to manage a fishery (May et al., 1979). The catch composition of aquatic species can give a considerable idea about the ecosystem of the community, however, the nature of the relationship among them is quite complex (Mazzoldi et al., 2014). Hence, it is essential to investigate the combined management measures for further improvement of its main components to augment productivity of coastal and offshore areas. However, this investigation will open a new avenue to modernize fisheries management strategies in the world. Therefore, this study aimed to explore the effects of integrated marine management measures by evaluating the change in production and abundance of selected species. Comparisons were also made between integrated FSRP and FSRP with the year-round open fishery.

\section{Materials and Methods}

The fishing closure not only prevents overexploitation but also gives a suitable place to spawn with an increased number of adult and larger broods to get a higher number of offspring in a season (Babcock et al., 1999). It also fulfills the goal of conservation of the fisheries resources in the future (Kincaid and Rose, 2014). Despite the high value of commercial species and consequent economic return, the Korean government started total allowable catch (TAC) to manage fish stocks in an extreme and conservative way since 1999. In addition, the seasonal closure has also been applied for putting fishing effort down to minimize overcapacity in this fishery (Lee and Midani, 2014a). Fisheries rebuilding operations were run for more than 10 years (2006-till date). The fish stock rebuilding plans (FSRP) were initiated by Korean Fisheries Resources Agency (FIRA) with some stock enhancement programs to rebuild commercially important species.

In this study, ten commercially important species in FSRP, sandfish (Arctoscopus japonicus), blue crab (Portunus pelagicus), octopus (Octopus minor), tokobushi abalone (Haliotis discus), skate ray (Hongeo koreana), cod (Gadus microcephalus), yellow croaker (Larimichthys polyactis), filefish (Stephanolepis cirrhifer), Korean flounder (Paralichthys olivaceus), and purplish Washington clam (Saxidomus purpuratus) were considered to evaluate the management policies to get a fruitful way for implementing target-oriented measures. Among these, tokobushi abalone, cod, filefish, Korean flounder and purplish Washington clam were caught year-round without fishing closure. Annual landings of rest five marine species namely sandfish, blue crab, octopus, skate ray and yellow croaker were considered for drawing inference on the effects of combination between FSRP and seasonal fishing closure. To know the landing variation during the management period, total productions in metric ton (MT) of five species, which 
were included in the seasonal closure policy, was calculated as:

$$
T P C=\sum_{t=1}^{n} P_{t}
$$

where, TPC is the total annual production (MT) of all species regarding closed season policy. $n$ represents a total number of species and $\mathrm{P}_{\mathrm{t}}$ indicates catch (MT) of species at time t. Similarly, total annual production of year-round open fishing species was calculated as:

$$
\text { TPOF }=\sum_{t=1}^{n} P_{t}
$$

where, TPOF denotes the total amount of annual production (MT) of five species concerning year-round open fishing policy; $n$ represents a total number of species and $P_{t}$ corresponds catch (MT) at time t. The annual overall production (OP) in MT was obtained as:

$$
\mathrm{OP}=\mathrm{TPC}+\mathrm{TPOF}
$$

where, OP is the overall production (MT) of selected ten commercial species in Korea. Here, TPC and TPOF were added to compute yearly OP.

Catch per unit effort (CPUE): Generally, CPUE is estimated by dividing annual fish landing amount by the total number of fishing trips in a year. Moreover, CPUE can also be calculated by considering fishing days and vessel numbers. CPUE is one of the important indices of species abundance (Chen and Chiu, 2009). However, it is not a firm indicator of stock abundance since it can be influenced by some factors (Harley et al., 2001). Usually, these factors affect fish harvest from the sea during fishing operation (Maunder et al., 2006). Like other factors, vessel's capacity in gross registered tonnage (GRT) was found as a significant contributor to CPUE (Parente, 2004). Thus, CPUE was calculated by applying GRT in this investigation. Catch per unit effort was calculated as:

$$
C_{t}=P_{t} / T_{t}
$$

where, $C$ is the catch per unit effort (CPUE) for fish species (MT $\left.\mathrm{GRT}^{-1} \mathrm{yr}^{-1}\right) ; \mathrm{C}_{t}$ is the CPUE for the year $t ; \mathrm{P}_{\mathrm{t}}$ represents fish catch for year tand $T_{t}$ indicates $G R T$ of fishing vessels for the year $t$.

Seasonal fishing closure impact: Significant changes in CPUE were measured and also observed the 5 -yr impact on species biomass by computing average CPUE for five years during FSRP as:

$$
\mathrm{C}_{5}=\frac{1}{5} \sum_{\mathrm{t}=1}^{5} \mathrm{C}_{\mathrm{t}}
$$

where, $\mathrm{C}_{5}$ is the mean CPUE (MT GRT ${ }^{-1} \mathrm{yr}^{-1}$ ) of included species in closed fishing season measures for the first five years of FSRP; $C_{t}$ indicates CPUE (MT GRT ${ }^{-1} \mathrm{yr}^{-1}$ ) of species for the year t. Likewise, the ten-year impact of seasonal closure on species, the CPUE was calculated as:

$$
\mathrm{C}_{10}=\frac{1}{10} \sum_{\mathrm{t}=1}^{10} \mathrm{C}_{\mathrm{t}}
$$

where, $\mathrm{C}_{10}$ is the mean CPUE (MT GRT ${ }^{-1} \mathrm{yr}^{-1}$ ) of a species for ten years during FSRP; $\mathrm{C}_{t}$ indicates CPUE (MT GRT ${ }^{-1} \mathrm{yr}^{-1}$ ) of species for yeart.

Year-round open fishing impacts: In contrast to seasonal closure, whole year open fishing practice is also important to meet-up fish market and processing industry demand for exporting to another country or supply required dietary protein and employment to local community. However, this condition increases fishing pressure, leading to stock vulnerability. Therefore, within the FSRP period of first 5-yr impact of yearround open fishing on species, the CPUE was calculated as:

$$
\mathrm{OF}_{5}=\frac{1}{5} \sum_{\mathrm{t}=1}^{5} \mathrm{C}_{\mathrm{t}}
$$

where, $\mathrm{OF}_{5}$ is the mean CPUE (MT GRT' $\mathrm{yr}^{-1}$ ) of a whole year open-fishing species for first five years during FSRP; $C_{t}$ indicates CPUE (MT GRT'-1 $\mathrm{yr}^{-1}$ ) of species from all year long open-fishing policy for the year $t$. In the same way, the ten-year impact of whole year open-fishing on species, the CPUE was computed as:

$$
\mathrm{OF}_{10}=\frac{1}{10} \Sigma_{\mathrm{t}=1}^{10} \mathrm{C}_{\mathrm{t}}
$$

where, $\mathrm{OF}_{10}$ is the mean CPUE (MT GRT ${ }^{-1} \mathrm{yr}^{-1}$ ) of a whole year open-fishing species for first ten years during FSRP; $C_{t}$ indicates CPUE (MT GRT'-1 $\mathrm{yr}^{-1}$ ) of species from all year long open-fishing policy for the yeart.

Short-term (5-yr) observation on abundance of a species will not give enough support to make fruitful policies. Besides, long-term (10-yr) monitoring on species abundance can play an effective role to design sustainable plans for managing a fishery. In addition, period of fisheries stocks recovery will be easier to determine by comparing between short-term and long-term impacts on stock abundance.

Pearson correlation: Pearson correlation coefficient was computed to determine the relationships among CPUE of different species in both seasonal closed-fishing and year-round open fishing management measures with the FSRP. The coefficient of correlation will indicates the nature of fluctuations among selected species (Mazzoldi et al., 2014).

Regression model: Among five species in a seasonally closed fishery group, blue crab was correlated significantly with most of the species (Table 5). Therefore, first regression model was formulated to examine the species which influenced the blue crab CPUE in the integrated management. Similarly, cod was associated significantly with most of the species in year-round open fishery group (Table 7). Thus, second regression model was also developed to assess the responsible species in changing cod CPUE from year-round open fishery. 
Model 1: Blue crab CPUE: As mentioned in the background on some selected species, blue crab CPUE might have been influenced by some other species. Accordingly, it was hypothesized that blue crab CPUE was influenced by CPUE of some other species: sandfish $\left(X_{1}\right)$, octopus $\left(X_{2}\right)$, skate ray $\left(X_{3}\right)$ and yellow croaker $\left(X_{4}\right)$. The model was defined as:

$$
Y=a+b_{1} X_{1}+b_{2} X_{2}+b_{3} X_{3}+b_{4} X_{4}
$$

where, $Y$ is the dependent variable blue crab CPUE; $a$ is the intercept, and $b_{1}, b_{2}, b_{3}$, and $b_{4}$ are the coefficient of independent variables $\mathrm{X}_{1}, \mathrm{X}_{2}, \mathrm{X}_{3}$ and $\mathrm{X}_{4}$, respectively.

Model 2: Cod CPUE: Similar to blue crab CPUE model, another model was formulated to examine the species influencing the cod CPUE, included in a year-round open fishing category. As observed, cod landing might have been influenced by some other species. Hence, it was hypothesized that cod CPUE was influenced by CPUE of a couple of other species: tokobushi abalone $\left(X_{1}\right)$, filefish $\left(X_{2}\right)$, Korean flounder $\left(X_{3}\right)$ and purplish Washington clam $\left(X_{4}\right)$. The model was defined as:

$$
Y=a+b_{1} X_{1}+b_{2} X_{2}+b_{3} X_{3}+b_{4} X_{4}
$$

Data analysis: Statistical Package for Social Sciences (SPSS) software was used to perform the data analysis. Data were obtained from KFA (2017), an official data source of Korean Fisheries Association. The collected data were compiled, tabulated, coded and analyzed in accordance with the objectives of this study. t-test was applied to see significant improvement in the abundance of species through integrated management policy. To see the relationships within species abundance (CPUE), the coefficient of Pearson correlation and coefficient of regression were also computed.

\section{Results and Discussion}

Overall production: The total annual catch from seasonally closed and year-round open fishery production from 1991 to 2016 is shown in Table 1. Among the OPs, the highest production was 155,842 MT and the whole amount was 2,200,389 MT, in which, $68 \%$ landing came from annually harvested species in seasonally closed fishery. In contrast, almost one-third (32\%) of OP came from the year-round open fishery during 1991-2016. The highest production of the year-round open fishery was 86,550 MT. In contrast, the highest landing of the seasonally closed fishery was estimated to be 103,014 MT(Table 1).

FSRP has been continuously reestablishing fish stock abundance since 2006. The production of closed season fishery was found to be higher during the FSRP period than FSRP as applied before (Fig. 1). Though the production of the year-round open fishery reached an optimum level in the early 2010s, it started to decline again in 2015. The lowest annual catch was estimated to be 14,652 MT in year-round open fishery from 1991 to 2016. In addition, the standard deviation of productions of the seasonally closed fishery was higher than the year-round open fishery. This clearly indicates the heterogenetic nature of

Table 1 : Production scenarios of ten commercial fish species during 1991-2016

\begin{tabular}{llll}
\hline Measurements & \multicolumn{3}{l}{ Landing (MT) } \\
\cline { 2 - 4 } & Seasonally closed fishery (TPC) & Year-round open fishery (TPOF) & Overall production (OP) \\
\hline $\mathrm{n}$ & 26 & 26 & 26 \\
Average & 57,555 & 27,076 & 84,630 \\
Median & 54,452 & 22,387 & 82,879 \\
Minimum & 23,867 & 14,652 & 43,589 \\
Maximum & 103,014 & 86,550 & 155,842 \\
Standard deviation & 20,636 & 14,778 & 27,342 \\
Production & $1,496,418$ & 703,971 & $2,200,389$ \\
Share(\%) & 68 & 32 & 100 \\
\hline
\end{tabular}

Table 2 : Catch composition by species for year-round open fishery during 1990s-2010s

\begin{tabular}{llll}
\hline Species abundance & \multicolumn{3}{c}{ Decades } \\
\cline { 2 - 4 } & 1990s & 2000s & 2010s \\
\hline Cod (\%) & 01.67 & 22.04 & 34.52 \\
Tokobushiabalone (\%) & 00.51 & 00.25 & 00.04 \\
Filefish (\%) & 34.11 & 11.98 & 08.42 \\
Korean flounder (\%) & 53.89 & 44.89 & 48.49 \\
Purplish Washington clam (\%) & 09.82 & 20.84 & 08.54 \\
Total (\%) & 100.00 & 100.00 & 100.00 \\
\hline
\end{tabular}




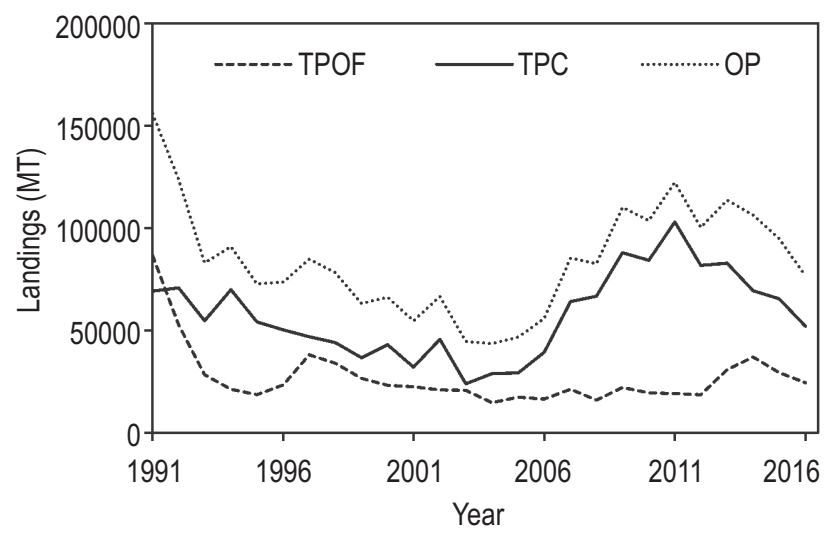

Fig. 1 : Annual (1991-2016) overall fish landings (OP) of ten commercial species, landings of five species in seasonal closure (TPC) and also five species in year-round open (TPOF) fishery in South Korea.

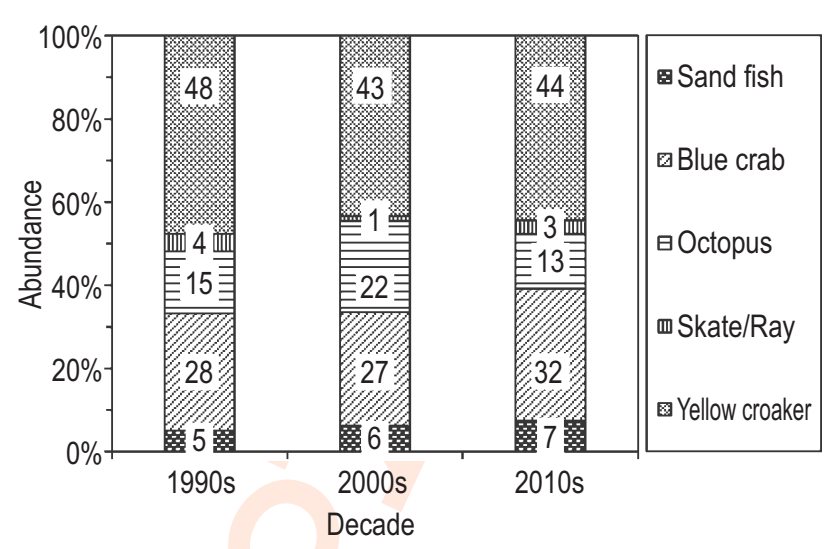

Fig. 2 : Catch composition by species for seasonally closed fishery during 1990s-2010s.

Table 3 : Effect of FSRP on stock abundance with or without seasonal closure

\begin{tabular}{|c|c|c|c|c|c|c|}
\hline \multirow[t]{3}{*}{ Species } & \multicolumn{2}{|c|}{$\begin{array}{r}\text { Five years CPUE } \\
\text { (MT GRT-1 yr-1) }\end{array}$} & \multirow[t]{3}{*}{$\begin{array}{l}\text { p-value } \\
\text { (t-test) }\end{array}$} & \multicolumn{2}{|c|}{$\begin{array}{l}\text { Ten years CPUE } \\
\text { (MT GRT-1 yr-1) }\end{array}$} & \multirow[t]{3}{*}{$\begin{array}{l}\text { p-value } \\
\text { (t-test) }\end{array}$} \\
\hline & $\begin{array}{l}\text { Before FSRP } \\
(2001-2005)\end{array}$ & $\begin{array}{l}\text { After FSRP } \\
\text { (2007-2011) }\end{array}$ & & $\begin{array}{l}\text { Before FSRP } \\
(1996-2005)\end{array}$ & $\begin{array}{l}\text { After FSRP } \\
(2007-2016)\end{array}$ & \\
\hline & Mean \pm SE & Mean \pm SE & & Mean \pm SE & Mean \pm SE & \\
\hline †Sandfish & $0.50918 \pm 0.188$ & $0.19324 \pm 0.009$ & 0.084 & $0.37765 \pm 0.145$ & $0.31179 \pm 0.051$ & 0.338 \\
\hline †Blue crab & $0.09554 \pm 0.028$ & $0.3973 \pm 0.090$ & 0.013 & $0.1058 \pm 0.014$ & $0.38033 \pm 0.054$ & 0.000 \\
\hline †Octopus & $0.09244 \pm 0.016$ & $0.1901 \pm 0.015$ & 0.001 & $0.12554 \pm 0.026$ & $0.17165 \pm 0.010$ & 0.063 \\
\hline †Skate ray & $0.00162 \pm 0.000$ & $0.03072 \pm 0.013$ & 0.042 & $0.00834 \pm 0.003$ & $0.02365 \pm 0.007$ & 0.027 \\
\hline †Yellow croaker & $0.16592 \pm 0.042$ & $0.8534 \pm 0.143$ & 0.003 & $0.15796 \pm 0.021$ & $0.84907 \pm 0.079$ & 0.000 \\
\hline$\ddagger$ Tokobushi abalone & $0.07512 \pm 0.011$ & $0.0904 \pm 0.033$ & 0.338 & $0.151 \pm 0.055$ & $0.0559 \pm 0.019$ & 0.065 \\
\hline$\ddagger$ Cod & $0.06236 \pm 0.006$ & $0.12834 \pm 0.028$ & 0.040 & $0.04287 \pm 0.011$ & $0.16289 \pm 0.020$ & 0.000 \\
\hline †Filefish & $0.0132 \pm 0.001$ & $0.04158 \pm 0.015$ & 0.070 & $0.03285 \pm 0.012$ & $0.03617 \pm 0.008$ & 0.409 \\
\hline ‡Korean flounder & $0.71172 \pm 0.138$ & $0.6405 \pm 0.034$ & 0.320 & $0.67641 \pm 0.173$ & $0.58654 \pm 0.054$ & 0.315 \\
\hline$\ddagger$ Purplish Washington clam & $5.19972 \pm 0.585$ & $2.0514 \pm 0.241$ & 0.002 & $4.30601 \pm 0.425$ & $1.74616 \pm 0.155$ & 0.000 \\
\hline
\end{tabular}

†FSRP with seasonal fishing closure; $¥ F S R P$ with year-round open fishery

production in the seasonally closed fishery. Between 2006 and 2016 , higher productions were observed in the seasonally closed fishery.

All the production lines went down continuously until 2004 (Fig. 1). As expected, finally fish catch began to rise just after the establishment of FSRP. Within FSRP management tenure, seasonal closure contributed more to recover vulnerable stocks rather than year-round capture fishery.

Species-wise catch composition: The five commercial species in the seasonally closed fishery policy during the last three decades were sandfish, blue crab, octopus, skate ray and yellow croaker. Species composition in the landing was changed moderately from 1990s-2010s (Fig. 2). In the 1990s, the production of yellow croaker was highest, followed by blue crab, octopus, sandfish and skate ray. So, catches from yellow croaker and blue crab fisheries were higher than other species in all the decades (Fig. 2). Besides, an abundance of sandfish, octopus and skate ray were comparatively lower. Among these three species, the catches of skate ray were lower for almost all decades. Moreover, changes in catches of sandfish were low in all the decades. However, in the year-round open fishery, another common five commercial species were cod, tokobushi abalone, filefish, Korean flounder and purplish Washington clam (Table 2).

Two finfish species, cod, and Korean flounder accounted for more than $80 \%$ of the total year-round open fishery catch in the 2010 s. From the 1990 s to 2010 s, only a sharp increase in catch share of cod was observed, while other species were somewhat unstable. Throughout the period, the abundance of filefish was also remarkably higher in the 1990s as compared to other 

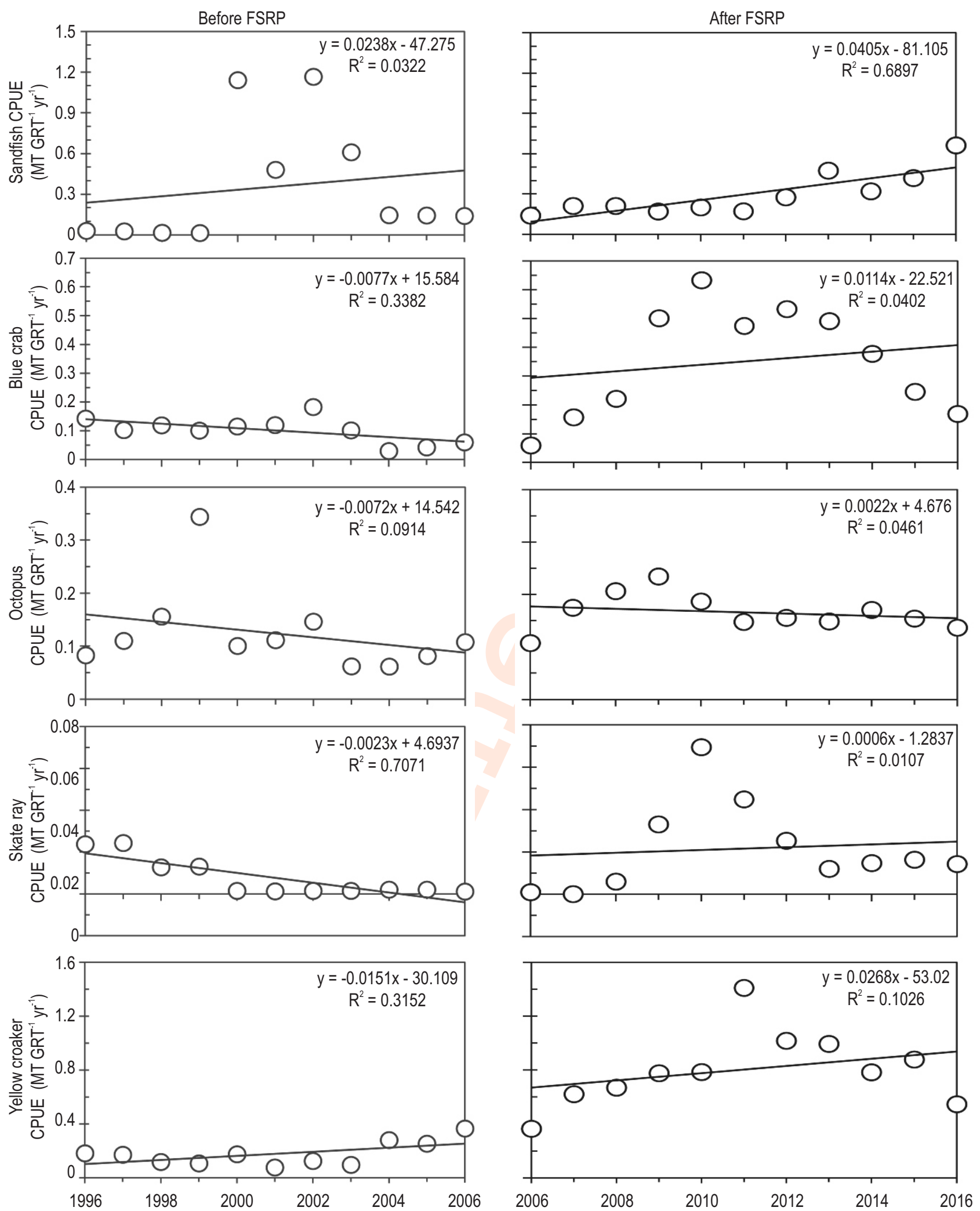

Year

Fig. 3 : CPUE Changes during integrated FSRP with seasonal closure. 
decades. Only Korean flounder showed negligible change in abundance throughout the consecutive three decades (1990s-2010s) (Table 2). In contrast, the share of tokobushi abalone in total landings was lowest all over the period. Similarly, purplish Washington clam also was found as a less productive species to achieve expected recovery for improving the status of abundance.

Species abundance trends in FSRP: The recovery trend in FSRP with seasonal fishing closure and the year-round open fishery is presented in Fig. 3 and 4, respectively. Policies such as a seasonal ban on fishing and FSRP may have played a positive role together to recover stocks biomass of five fish species in Korean marine ecosystem. Before FSRP, trends in CPUE of blue $\mathrm{crab}$ and skate ray were negative. Thereafter, these two species grew positively to an expected level after starting of FSRP. On the other hand, CPUE of sandfish and yellow croaker proceeded with a positive trend before and after FSRP. Although trends were positive for both situations, the slope of CPUE change was higher in the FSRP period. Thus, the abundance of both species increased remarkably during the FSRP period with seasonally closed fishing. In spite of implementing both FSRP and seasonal closure policies together, octopus merely remained negative trend but the slope of CPUE during the FSRP period was lower than before (Fig. 3)

In the year-round open fishery, CPUE trend of five spceies, namely purplish Washington clam, Korean flounder, filefish, cod, and tokobushi abalone were compared between the before and after effects of FSRP (Fig. 4). As a result, from 1996 to 2006, CPUE of tokobushi abalone varied between 0.564 and $0.351 \mathrm{MT} \mathrm{GRT}^{-1} \mathrm{yr}^{-1}$ with a sharper declining trend than that of the FSRP period. In contrast, CPUE of tokobushi abalone fluctuated within the range of 0.183-0.009 $\mathrm{MT} \mathrm{GRT}^{-1} \mathrm{yr}^{-1}$ during FSRP with a decreasing trend. Between 1996 and 2016, consistently increasing trend in CPUE was observed only for cod. CPUEs of Korean flounder and purplish Washington clam also increased during 1996-2006.

The trends of CPUEs of these species dropped throughout the FSRP period. Exceptionally, there is increasing trend in CPUE of filefish during FSRP with year-round fishing while decreasing trend before FSRP.

Integrated policy impacts: Average CPUEs for five years (5-yr) and ten years $(10-y r)$ of the species before policy integration were compared with the average CPUEs for five years (5-yr) and ten years (10-yr) of the same species after policy integration (Fig. 5; Table 3). Here, the average CPUE (MT GRT ${ }^{-1} \mathrm{yr}^{-1}$ ) values of blue crab, octopus, skate ray and yellow croaker after 5 -yr of FSRP increased significantly $(p<0.05)$ and higher than before FSRP. Similarly, the CPUE average of blue crab, skate ray and yellow croaker 10-yr after FSRP also improved significantly $(p<0.05)$ and were higher than before. Except for sandfish, blue crab, octopus, skate ray and yellow croaker were able to recover their abundance through policy integration of FSRP with seasonal closure. However, only sandfish failed to improve their abundance significantly.

The 5 and 10-year mean values of CPUE were also investigated for understanding the effect of FSRP without seasonal closure (Fig. 5; Table 3). At this point, these species were purplish Washington clam, Korean flounder, filefish, cod and tokobushi abalone. Surprisingly, 5 and 10-year CPUE means of only cod improved significantly $(p<0.05)$ after FSRP without seasonal closure. In contrast, 5 and 10 -year mean values of

Table 4 : Required period of time for FSRP to enhance the abundance of stocks in seasonal fishing closure and also in year-round open fishery policy

\begin{tabular}{|c|c|c|c|c|c|}
\hline \multirow[t]{2}{*}{ Policy } & \multirow[t]{2}{*}{ Species } & CPUE(C) in 2006 & $\mathrm{C}_{5}$ & $\mathrm{C}_{10}$ & \multirow{2}{*}{$\frac{C_{10}-C_{5}}{C_{5}} \times 100$} \\
\hline & & \multicolumn{3}{|c|}{ (MT GRT ${ }^{-1} \mathrm{yr}^{-1}$ ) } & \\
\hline \multirow[t]{2}{*}{$\begin{array}{l}\text { Seasonal closure } \\
\text { with FSRP }\end{array}$} & $\begin{array}{l}\text { Sandfish } \\
\text { Blue crab } \\
\text { Octopus } \\
\text { Skate ray } \\
\text { Yellow croaker }\end{array}$ & $\begin{array}{l}0.140 \\
0.060 \\
0.108 \\
0.001 \\
0.365\end{array}$ & $\begin{array}{l}0.193 \\
0.397 \\
0.190 \\
0.0307 \\
0.853 \\
\end{array}$ & $\begin{array}{l}0.311 \\
0.380 \\
0.171 \\
0.0236 \\
0.849\end{array}$ & $\begin{array}{l}61.35 \\
-4.46 \\
-10.75 \\
-23.01 \\
-0.51\end{array}$ \\
\hline & & \multicolumn{3}{|c|}{$\left(\mathrm{MT} \mathrm{GRT}^{-1} \mathrm{yr}^{-1}\right)$} & $\frac{O F_{10}-O F_{5}}{O F_{5}} \times 100$ \\
\hline $\begin{array}{l}\text { Year-round open fishery } \\
\text { with FSRP }\end{array}$ & $\begin{array}{l}\text { Tokobushi abalone } \\
\text { Cod } \\
\text { Filefish } \\
\text { Korean flounder } \\
\text { Purplish Washington clam }\end{array}$ & $\begin{array}{l}0.056 \\
0.093 \\
0.011 \\
0.402 \\
2.566\end{array}$ & $\begin{array}{l}0.090 \\
0.128 \\
0.041 \\
0.641 \\
2.051\end{array}$ & $\begin{array}{l}0.056 \\
0.162 \\
0.036 \\
0.586 \\
1.746\end{array}$ & $\begin{array}{l}-27.55 \\
26.92 \\
-13.01 \\
-8.42 \\
-14.88\end{array}$ \\
\hline
\end{tabular}



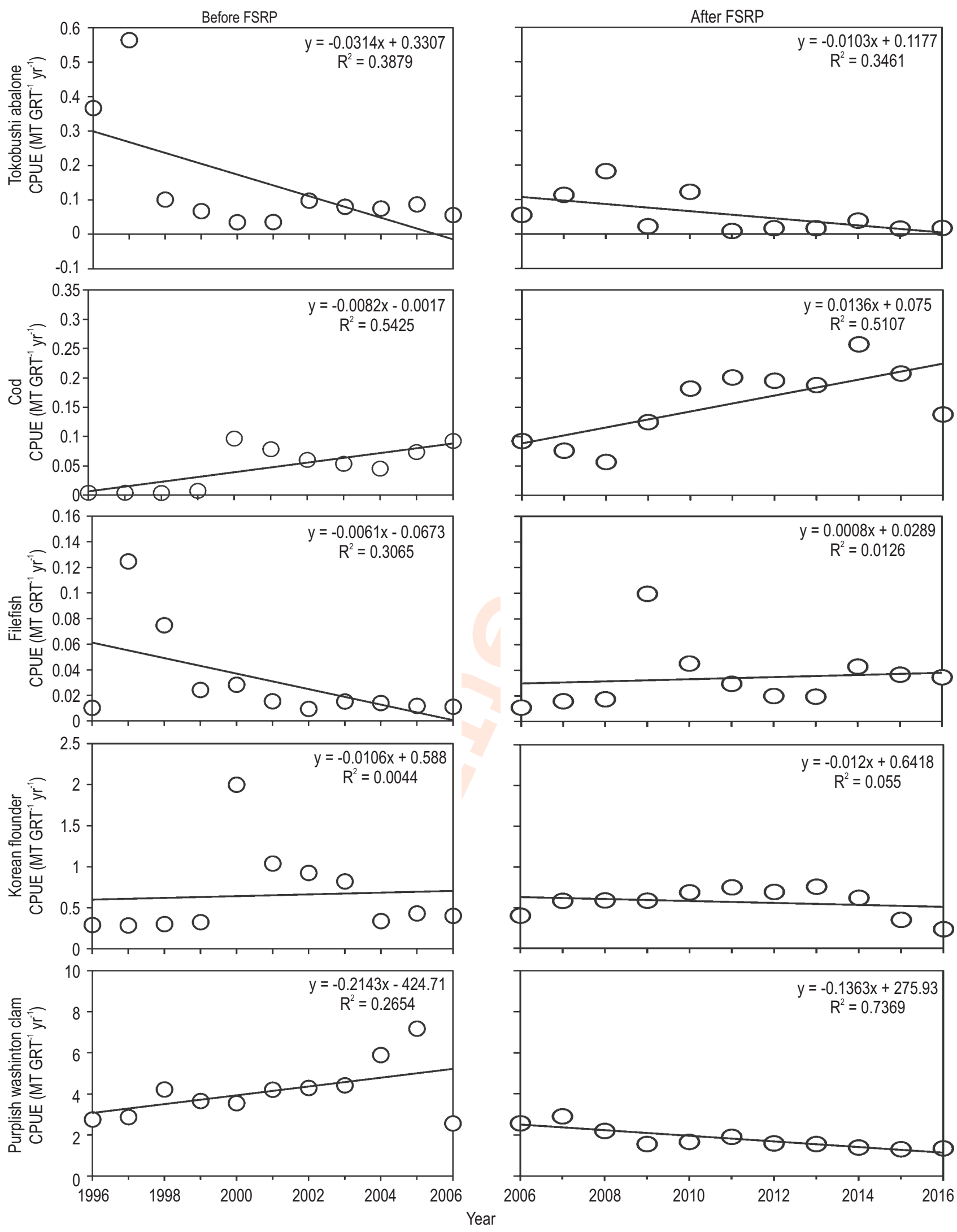

Fig. 4 : Changes in CPUE during FSRP with year-round open fishery policy. 
(A)
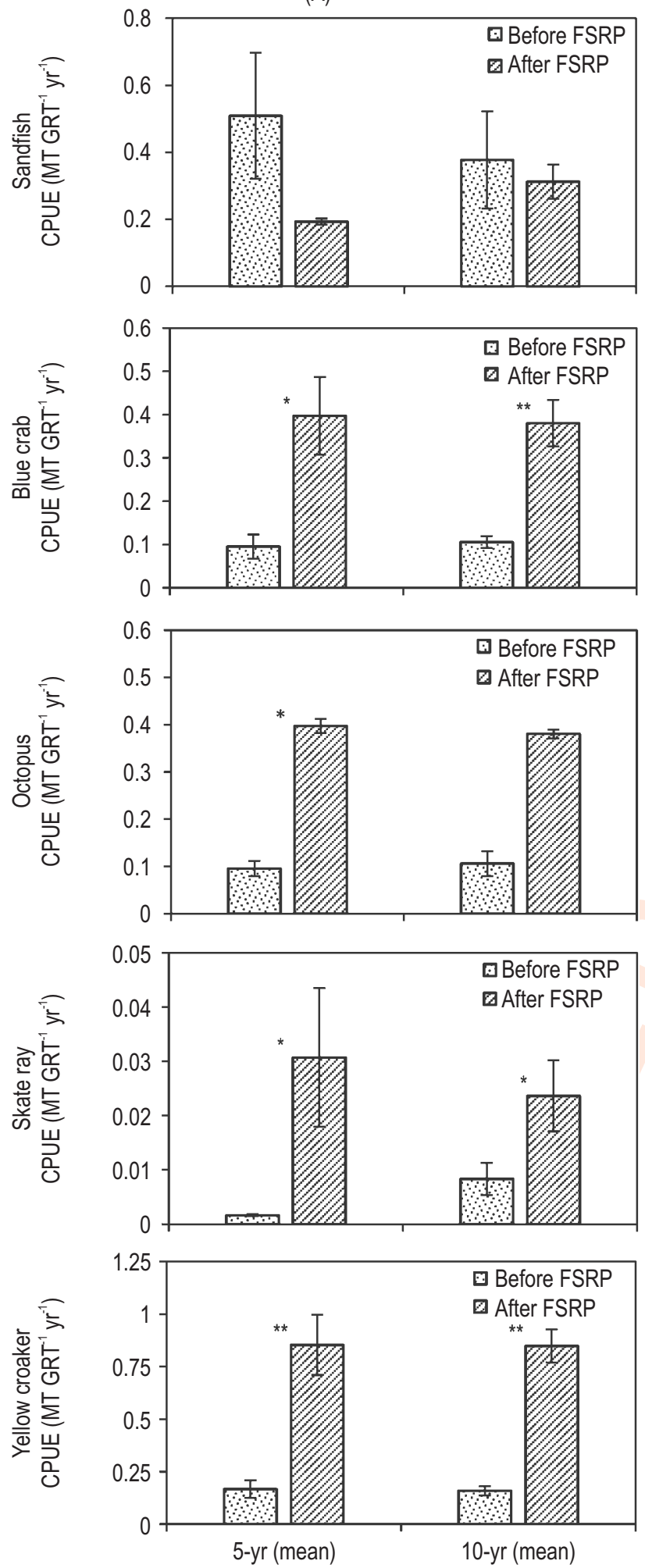

(B)
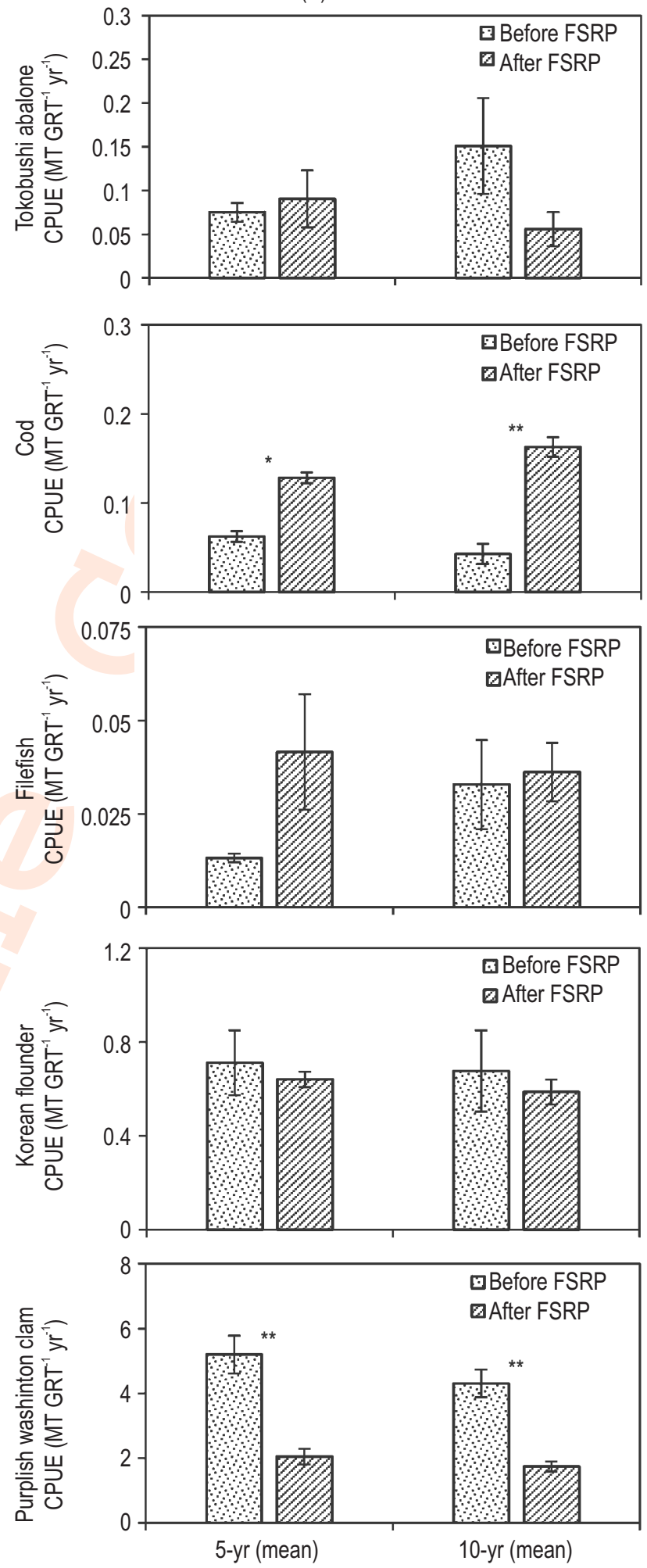

${ }^{* *} P<0.01 ;{ }^{*} P<0.05$

Fig. 5 : Comparison of average CPUE between five years (5-yr) and ten years (10-yr) before FSRP, and five years (5-yr) and ten years (10-yr) after FSRP. The graphs of FSRP with seasonal closure and FSRP with year-round open fishery are shown as (A) and (B), respectively. 
Table 5 : Correlation matrix of CPUEs of species in FSRP with seasonal closure

\begin{tabular}{llllll}
\hline & Blue crab & Skate ray & Yellow croaker & Sandfish & Octopus \\
\hline Blue crab & 1 & & & & \\
Skate ray & $0.762^{* *}$ & 1 & & & \\
Yellow croaker & $0.811^{* *}$ & $0.545^{*}$ & 1 & 1 & 1 \\
Sandfish & -0.053 & -0.329 & -0.146 & -0.234 & 1 \\
Octopus & 0.357 & 0.288 & 0.244 & & \\
\hline
\end{tabular}

${ }^{* *} p<0.01 ;{ }^{*} p<0.05$

Table 6: Coefficient of independent variables in the blue crab CPUE model

\begin{tabular}{|c|c|c|c|c|c|}
\hline \multirow[t]{2}{*}{ Variables } & \multicolumn{2}{|c|}{ Unstandardized coefficients } & \multirow{2}{*}{$\begin{array}{l}\text { Standardized } \\
\text { coefficients }\end{array}$} & \multirow[t]{2}{*}{$t$} & \multirow[t]{2}{*}{$\mathrm{p}$} \\
\hline & B & Standard error & & & \\
\hline Constant & 0.026 & 0.032 & & 0.837 & 0.414 \\
\hline Yellow croaker & 0.269 & 0.060 & 0.563 & 4.512 & 0.000 \\
\hline Skate ray & 4.848 & 1.330 & 0.455 & 3.647 & 0.002 \\
\hline \multicolumn{6}{|c|}{ Summary of Blue crab CPUE model } \\
\hline Model & $\mathrm{R}$ & R square & Adjusted R square & Standard error & \\
\hline 1 & $0.811 \dagger$ & 0.657 & 0.639 & 0.11135 & \\
\hline 2 & $0.896 \ddagger$ & 0.803 & 0.781 & 0.08675 & \\
\hline
\end{tabular}

†Predictors: (Constant), Yellow croaker; $¥$ Predictors: (Constant), Yellow croaker, Skate ray

CPUE of purplish Washington clam decreased significantly $(p<$ 0.05 ) after FSRP without seasonal closure. Besides, other three species could have changed their abundance insignificantly $(p>$ $0.05)$ in FSRP with the year-round open fishery.

Nature of stock recovery during FSRP: Table 4 depicts the differences between the 5-yr $\left(\mathrm{C}_{5} / \mathrm{OF}_{5}\right)$ and $10-\mathrm{yr}\left(\mathrm{C}_{10} / \mathrm{OF}_{10}\right)$ mean CPUE by species during the period of FSRP. In FSRP with seasonal closure, most of the species showed better recovery in five years than ten years of FSRP. Only the sandfish recovered spontaneously not only in five years but also in ten years of FSRP. The mean CPUEs of yellow croaker were almost the same in both the 5-yr and 10-yr. Blue crab stood second in abundance, followed by skate ray, sandfish and octopus in the first 5-yr of FSRP. In contrast, mean CPUE of blue crab, octopus, skate ray and yellow croaker in 10-yr of FSRP was found lower than 5-yr mean CPUE. However, the CPUEs of the 5-yr and 10-yr were higher than the CPUE in 2006. It told that FSRP with seasonal closure recovered stocks remarkably but this programme should replan again for a better performance in the long run. Likewise, in the year-round open fishery, only cod gained the CPUE higher in the $10-y r$ than the $5-y r$ mean. The mean CPUE of purplish Washington clam was the highest in the first 5-yr during FSRP than the 10-yr. Similarly, four species showed lower CPUE mean in 10-yr of FSRP. Surprisingly, only tokobushi abalone showed the same in CPUE both in 2006 and 10-yr mean.

Variation of abundance with seasonally closed fishery: In the same management policy, there is a possibility to remain similar fluctuation in CPUEs of species over the years. The blue crab was one of the dominant species and showed an increasing trend in CPUE. Similarly, skate ray, octopus and yellow croaker followed the same trend as like as blue crab. In fact, CPUE of blue crab and yellow croaker were highly correlated with each other (Pearson's correlation: $r=0.811, p<0.01$ ), displaying not only alike trends but also significantly similar variations (Table 5).

In addition, skate ray showed high and positive correlation $(r=0.762, p<0.01)$ with blue crab throughout the period (1996-2016). Moreover, octopus also showed a similar pattern in CPUE trends in 1996-2016. In contrast, sandfish depicted quite different and negative trend in CPUE with blue crab from the same group of species. Two independent variables, namely, yellow croaker and skate ray were associated significantly $(r=0.545, p<0.05)$ with the magnitude of the dependent variable, CPUE value of blue crab. Again, these species were included in step-wise regression analysis and found higher multiple $R$ and $R^{2}$ values and also had gained more ability to explain in the model. These two variables can explain $78 \%$ of the variation in blue crab CPUE. Thus, yellow croaker and skate ray had a positive contribution to the blue crab. Among these two species, CPUE of yellow croaker influenced the most ( 0.563 unit), followed by skate ray ( 0.455 unit). Therefore, an increase in one unit of CPUE of yellow croaker leads to increase by 0.563 unit CPUE of blue crab. Likewise, 0.455 unit CPUE of blue crab would be increased if one unit of CPUE of skate ray was increased (Table 6). 
Table 7 : Correlation matrix of CPUEs of species in FSRP with open fishery

\begin{tabular}{llllll}
\hline & Cod & Tokobushi abalone & Purplish Washington clam & Filefish & Korean flounder \\
\hline Cod & 1 & & & & \\
Tokobushiabalone & $-0.551^{* *}$ & 1 & 1 & & \\
Purplish Washington clam & $-0.619^{* *}$ & 0.076 & -0.259 & 1 & 1 \\
Filefish & -0.062 & $0.435^{*}$ & 0.049 & -0.206 & 1 \\
Korean flounder & 0.174 & -0.299 & & & \\
\hline
\end{tabular}

${ }^{* *} p<0.01 ;{ }^{*} p<0.05$

Table 8: Coefficient of independent variables included in the cod CPUE model

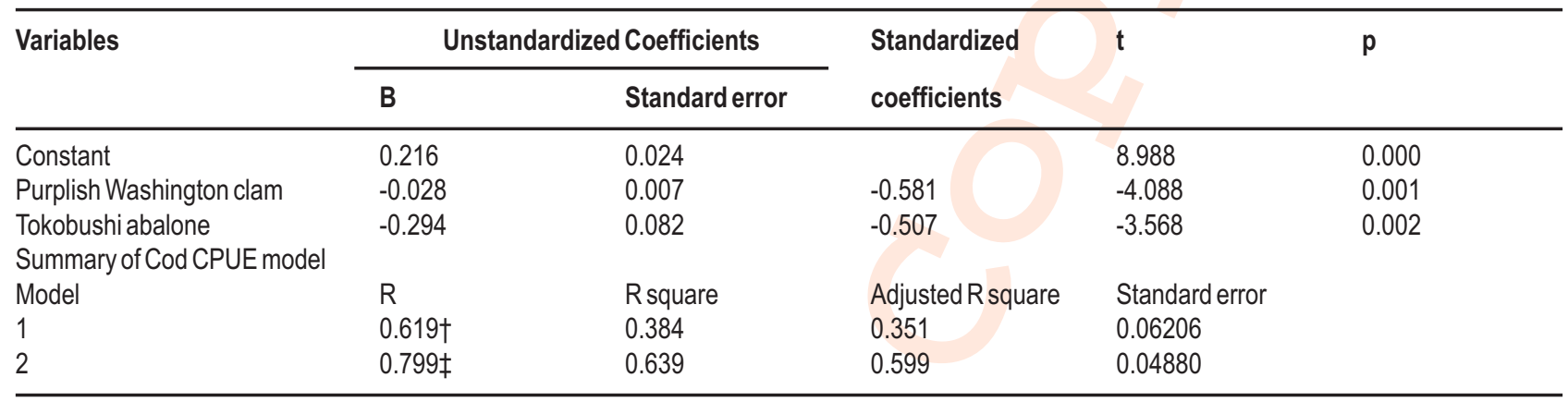

† Predictors: (Constant), Purplish Washington clam; † Predictors: (Constant), Purplish Washington clam, Tokobushi abalone

Variation in species abundance in the year-round open fishery: Five commercial species, such as cod, tokobushi abalone, purplish Washington clam, filefish, and Korean flounder belong to the year-round open fishery. Among these species, tokobushi abalone and purplish Washington clam were strongly correlated with the response species, cod. A high negative correlation $(r=-0.55, p<0.01)$ was found between tokobushi abalone and cod. Similarly, purplish Washington clam and cod were associated negatively with each other $(r=-0.62, p<0.01)$. Besides, a lower and weaker positive correlation $(r=0.43, p<$ 0.05 ) was also found between filefish and tokobushi abalone (Table 7).

Thus, purplish Washington clam and tokobushi abalone were correlated strongly and significantly with cod. Due to a weak and insignificant relationship of Korean flounder and filefish with cod, only two species, purplish Washington clam and tokobushi abalone were added in the regression analysis further to make a clear conception about the amount of change in abundance (CPUE) due to an influence of one species on another during the period of 1996-2016 (Table 8).

Consequently, in the regression model, two independent variables i.e. CPUE values of purplish Washington clam and tokobushi abalone were associated significantly with cod. Therefore, they were considered to put in step by step regression analysis. As a result, there was found an expected higher $\mathrm{R}$ and $R^{2}$ values which improved the ability to explain the model more consistently. CPUE of purplish Washington clam and tokobushi abalone can explain $60 \%$ variation in CPUE of cod. Thus, one unit decrease in CPUE of purplish Washington clam will lead to an increase of 0.58 unit in CPUE of cod. Likewise, 0.50 unit of CPUE of cod would be increased if one unit CPUE of tokobushi abalone were decreased (Table 8).

Integrated management effect: Nowadays, single fishery management turns into ecosystem-based fisheries management (EBFM), an integrated approach between marine ecosystems and coastal communities (Hare, 2020; Marasco et al., 2007). In addition, some laws were also modified in European fishery to manage resources by integrating broad conservation and sustainable resource utilization as a prime goal (Gullestad et al., 2017). Similarly, this study was emphasized to integrate management measures for recovering depleted marine stocks in Korea. Thus, it has a unique feature in terms of ecosystem-based fisheries management issues. Moreover, this one is also the first attempt in South Korea to consider management integration with an aim to open a sustainable way for the restoration of marine stocks and increment of their productivity as well.

In this study, the seasonal closure possibly a nice way of remedy to a sudden decline in fisheries stocks since the CPUE of stocks from closed fishery was higher than open fishery throughout the time series (Table 3). Apparently, biodiversity and ecosystem structure would be effectively improved by establishing marine protection to prevent fishermen from 
overexploitation (Giraldi-Costa et al., 2020; Russ and Alcala, 2011). Marine productivity depends on the restoration of depleted biodiversity and suitable structural modification of ecosystem (Worm et al., 2006). So, the main influence of the closed fishing season was to enhance the amount in fish landing (Rola et al., 2018). The percentages of production share in seasonal closure and year-round open fishery were 68 and 32 , respectively (Table 1). During that period, blue crab and yellow croaker were found as the dominant species in the seasonally closed fishery (Fig. 2). In year-round open fishery, Korean flounder and cod were observed as one of the abundant species in almost all decades (Table 2).

Integration of FSRP and seasonally fishing closure provided increasing trend in CPUE of most of the species (Fig. 3). After the beginning of FSRP with seasonal closure, four species showed significantly higher CPUE mean (Fig. 5). Only sandfish could not give higher and significant mean after FSRP with seasonal closure. However, it was reported that a good environment in the ocean is one of the fundamental factors to recover the sandfish (Watanabe et al., 2004). All environmental factor in the sea might have not been appropriate for rebuilding sandfish through FSRP with seasonal closure. Further, we observed that the blue crab showed positive and significant correlation with yellow croaker and skate ray (Table 5). It indicates that three species from FSRP with seasonal closure were continued similar fluctuation over the time period. In terms of trophic level, yellow croaker and skate ray are at a higher level than the blue crab (Zhang et al., 2007). But, there might no possibility of predation on blue crab by croaker (Guillory and Elliot, 2001). However, except cod, year-round open fishery of tokobushi abalone and filefish depicted decreasing trends in CPUE of purplish Washington clam and Korean flounder (Fig. 4). Here the only CPUE of cod was increased significantly without seasonal closure during FSRP but only the mean CPUE was reduced significantly in purplish Washington clam (Fig. 5). Cod is a migratory species and migrates seasonally due to breed and to feed (Alderdice and Forrester, 1971; Savin, 2007). Therefore, common seasonal closure may not require to recover cod stock (Clarke etal., 2015).

Recovery of stocks was higher in the first 5 -yr than the 10yr during the period of FSRP (Table 4). However, in fully closed fishery, it took more than 10 years to rebuild mackerel in the United States (Benson et al., 2016). In contrast, long time closed fishery may not only hamper the income of fishermen but also the workers in fish processing factory in the long run (Rola et al., 2018). In Korea, the government initiated seasonal fishing closure by considering employment issues of the coastal peoples. However, government agencies should be thinking about the remodeling of ecosystem-based stock rebuilding plans every five years to get a viable output.

Cod showed a negative correlation with tokobushi abalone and purplish Washington clam (Table 7). Cod predates on benthos communities especially crustaceans and also bivalves (Yamamura et al., 1993). It might be a reason for growing cod population vigorously but may also be a vital cause to deplete purplish Washington clam continuously. So, in year-round open fishery, cod took advantages of growing through eating up all purplish Washington clam as well. Besides, purplish Washington clam could not increase due to predation as well as seasonal closure could not be implemented. This situation is indicating a warning for a possibility to reduce benthic communities through unexpected predation on them. Therefore, it advocates that the integration of management measures played a useful role in recovering fisheries stocks in South Korea.

Strengthening FSRP with seasonal closure has become an ideal option for getting more production as well as rebuilding fish stocks successfully. Overall production trend in year-round open fishery was lower than seasonally closed fishery throughout the period. Over the few decades, blue crab and yellow croaker showed a stable larger catch in the seasonally closed fishery. However, in the year-round open fishery, species-wise production was quite unstable. Integration of FSRP with seasonally fishing closure revealed increasing trend in CPUE of four species, except for sandfish. Although, the year-round open fishery gave decreasing trend in CPUE of purplish Washington clam. Recovery of overall stocks was higher in first 5-yr than 10-yr of FSRP. Species in closed fishery demonstrated a sound relationship with similar fluctuations within the ecosystem. For making a sustainable fishery, further ecological studies are required to update the existing components of the FSRP in every five years and to find out a possible cause of disappearing purplish Washington clam with increasing cod population.

\section{Acknowledgments}

We acknowledge that this work was supported by a Research Grant 2020 from Pukyong National University, Korea. We also appreciate FIRA members for their cordial help by providing information in conducting this research.

\section{References}

Alderdice, D.F. and C.R. Forrester: Effects of salinity, temperature, and dissolved oxygen on early development of the Pacific cod (Gadus macrocephalus). J. Fish. Res. Bd. Can., 28, 882-902 (1971).

Babcock, R.C., S. Kelly, N.T. Shears, J.W. Walker and T.J. Willis: Changes in community structure in temperate marine reserves. Mar. Ecol. Prog. Ser., 189, 125-134 (1999).

Benson, A.J., A.B. Cooper and T.R. Carruthers: An evaluation of rebuilding policies for U.S. fisheries. PLOS ONE, 11, 1-15 (2016).

Chen, C.S. and T.S. Chiu: Standardising the CPUE for the Illex argentinus fishery in the Southwest Atlantic. Fish. Sci., 75, 265-272 (2009).

Clarke, J., D.M. Bailey and P.J. Wright: Evaluating the effectiveness of a seasonal spawning area closure. ICES J. Mar. Sci., 72, 2627-2637 (2015).

Demestre, M., S.D. Juan, P. Sartor and A. Ligas: Seasonal closures as a 
measure of trawling effort control in two Mediterranean trawling grounds: effects on epibenthic communities. Mar. Pol. Bull., 56, 1765-1773 (2008).

Giraldi-Costa, A.C., R.P. Medeiros and L.M. Tiepolo: Step zero of marine protected areas of Brazil. Mar. Pol., 120, 104-119 (2020).

Guillory, V. and M. Elliot: A Review of blue Crab Predators. In: Proceedings of the blue crab symposium (Eds. V. Guillory and $\mathrm{H}$. Perry). The Crustacean Society Annual Summer Meeting, US: Ocean Springs, pp. 28-4 (2001).

Gullestad, P., A.M. Abotnes, G. Bakke, M. Skern-Mauritzen, K. Nedreaas and G. Søvik: Towards ecosystem-based fisheries management in Norway-Practical tools for keeping track of relevant issues and prioritising management efforts. Mar. Pol., 77, 104-110 (2017).

Hare, J.A.: Ten lessons from the frontlines of science in support of fisheries management. ICES J. Mar. Sci. , 77, 870-877 (2020).

Harley, S.J., R.A. Myers and A. Dunn: Is catch-per-unit-effort proportional to abundance? Can. J. Fis. Aqua. Sci., 58, 1760-1772 (2001).

KFA: Korean Fisheries Yearbook, Korean Fisheries Association, Republic of Korea (2017).

Kincaid, K.B. and G.A. Rose: Why fishers want a closed area in their fishing grounds: Exploring perceptions and attitudes to sustainable fisheries and conservation 10 years post closure in Labrador, Canada. Mar. Pol., 46, 84-90 (2014).

Lee, S.G. and A.R. Midani: National comprehensive approaches for rebuilding fisheries in South Korea. Mar. Pol., 45, 156-162 (2014a).

Lee, S.G. and A.R. Midani: Analysing the strategies and level of economic creativity in Korean fisheries. J. Fis. and Mar. Sci. Edu., 26, 1322-1331 (2014b).

Lee, S.G. and A.R. Midani: Productivity change under the vessel buyback program in Korean fisheries. Fish. Sci., 81, 21-28 (2015).

Marasco, R.J., D. Goodman, C.B. Grimes, P.W. Lawson, A.E. Punt and T.J. Quinn II: Ecosystem-based fisheries management: Some practical suggestions. Canad. J. Fisher. Aqu. Sci., 64, 928-939 (2007).

Maunder, M.N., J.R. Sibert, A. Fonteneau, J. Hampton, P. Kleiber and S.J. Harley: Interpreting catch per unit effort data to assess the status of individual stocks and communities. ICES J. Mar. Sci., 63, 1373-1385 (2006).

May, R.M., J.R. Beddington, C.W. Clark, S.J. Holt and R.M. Laws: Management of multispecies fisheries. Science, 205, 267-277 (1979).

Mazzoldi, C., A. Sambo and E. Riginella: The Clodia database: a long time series of fishery data from the Adriatic Sea. Sci. D., 1, 140018 (2014).

Melnychuk, M.C., J.A. Banobi and R.A. Hilborn: Effects of management tactics on meeting conservation objectives for Western North American groundfish fisheries. PLoS ONE, 8, e56684 (2013).

Merayo, E., R. Nielsen, A. Hoff and M. Nielsen: Are individual transferable quotas an adequate solution to overfishing and overcapacity? Evidence from Danish fisheries. Mar. Pol., 87, 167-176 (2018).
Olesen, I., H.B. Bentsen, M. Phillips and R.W. Ponzoni: Can the global adoption of genetically improved farmed fish increase beyond 10\%, and how? J. Mar. Sci. Eng., 3, 240-266 (2015).

Parente, J.: Predictors of CPUE and standardization of fishing effort for the Portuguese coastal seine fleet. Fis. Res., 69, 381-387 (2004).

Pope, J.G.: Input and output controls: The practice of fishing effort and catch management in responsible fisheries, In: A fishery manager's guidebook (Eds.: K.L. Cochrane and S.M. Garcia). Italy: FAO and Wiley-Blackwell., pp. 220-252 (2009).

Rice, J.C. and S.M. Garcia: Fisheries, food security, climate change and biodiversity: characteristics of the sector and perspectives of emerging issues. ICES J. Mar. Sci., 68, 1343-1353 (2011).

Rola, A.C., T.A. Narvaez, M.R.A. Naguit, D.D. Elazegui, B.B.C. Brillo, M.M. Paunlagui, H.C. Jalotjot and C.P. Cervantes: Impact of the closed fishing season policy for sardines in Zamboanga Peninsula, Philippines. Mar. Pol., 87, 40-50 (2018).

Russ, G.R. and A.C. Alcala: Enhanced biodiversity beyond marine reserve boundaries: The cup spillith over. Ecol. Appl., 21, 241-250 (2011).

Savin, A.B.: Seasonal migrations of pacific cod Gadus macrocephalus (Gadidae) off the eastern coast of Kamchatka. J. Ichth., 47, 620-630 (2007).

Simões, S.M., G.S. Heckler and R.C. Costa: Reproductive period and recruitment of Penaeoidea shrimp on the Southeastern Brazilian Coast: implications for the closed season. Crustac., 90, 1177-1192 (2017).

Walker, K., A. Aranis and J.E. Contreras-Reyes: Possible criterion to estimate the juvenile reference length of common sardine (Strangomera bentincki) off central-Southern Chile. J. Mar. Sci. Eng., 6, 82 (2018).

Watanabe, K., H. Sugiyama, S. Sugishita, N. Suzuki and K. Sakuramoto: A management policy for North Japan sea sailfin sandfish Arctoscopus japonicus stock. International Institute of Fisheries Economics \& Trade, Proceedings, Japan (2004).

Worm, B., E.B. Barbier, N. Beaumont, J.E. Duffy, C. Folke, B.S. Halpern, J.B.C. Jackson, H.K. Lotze, F. Micheli, S.R. Palumbi, E. Sala, K.A. Selkoe, J.J. Stachowicz and R. Watson: Impacts of biodiversity loss on ocean ecosystem services. Science, 314, 787-790 (2006).

Yamamura, O., K. Watanabe and K. Shimazaki: Feeding Habits of Pacific Cod, Gadus Macrocephalus, off Eastern Hokkaido, North Japan. Proceedings of the NIPR Symposium on Polar Biology (1993).

Ye, Y., K. Cochrane, G. Bianchi, R. Willmann, J. Majkowski, M. Tandstad and F. Carocci: Rebuilding global fisheries: the World Summit Goal, costs and benefits. Fish Fish., 14, 174-185 (2013).

Zhang, C.I., J.H. Lim, Y. Kwon, H.J. Kang, D.H. Kim and Y.I. Seo: The current status of west sea fisheries resources and utilization in the context of fishery management of Korea. Ocean Coast. Manage., 102, 493-505 (2014).

Zhang, C.I., S.C. Yoon and J.B. Lee: Effects of the 1988/89 climatic regime shift on the structure and function of the southwestern Japan/East sea ecosystem. J. Mar. Syst., 67, 225-235 (2007). 